This article was downloaded by: [James Cook University]

On: 8 February 2011

Access details: Access Details: [subscription number 920712180]

Publisher Taylor \& Francis

Informa Ltd Registered in England and Wales Registered Number: 1072954 Registered office: Mortimer House, 3741 Mortimer Street, London W1T 3JH, UK

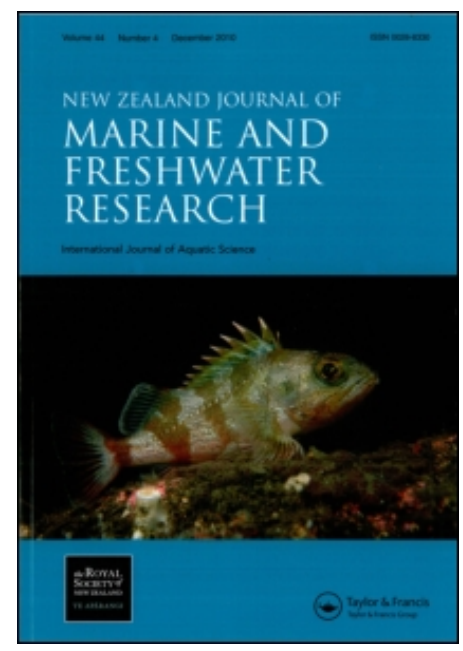

\title{
New Zealand Journal of Marine and Freshwater Research
}

Publication details, including instructions for authors and subscription information:

http://www.informaworld.com/smpp/title content=t918959567

\section{Highly localised distribution patterns of juvenile sea cucumber Australostichopus mollis \\ MJ Slater ; AG Carton ${ }^{\mathrm{b}}$; AG Jeffs ${ }^{\mathrm{c}}$}

${ }^{\text {a }}$ School of Marine Science and Technology, Newcastle University, Newcastle upon Tyne, UK ${ }^{\mathrm{b}}$ School of Marine and Tropical Biology, James Cook University, Townsville, Australia ${ }^{c}$ Leigh Marine

Laboratory, University of Auckland, Warkworth, New Zealand

First published on: 23 December 2010

To cite this Article Slater, MJ , Carton, AG and Jeffs, AG(2010) 'Highly localised distribution patterns of juvenile sea cucumber Australostichopus mollis', New Zealand Journal of Marine and Freshwater Research, 44: 4, 201 - 216, First published on: 23 December 2010 (iFirst)

To link to this Article: DOI: $10.1080 / 00288330.2010 .504526$

URL: http://dx.doi.org/10.1080/00288330.2010.504526

\section{PLEASE SCROLL DOWN FOR ARTICLE}

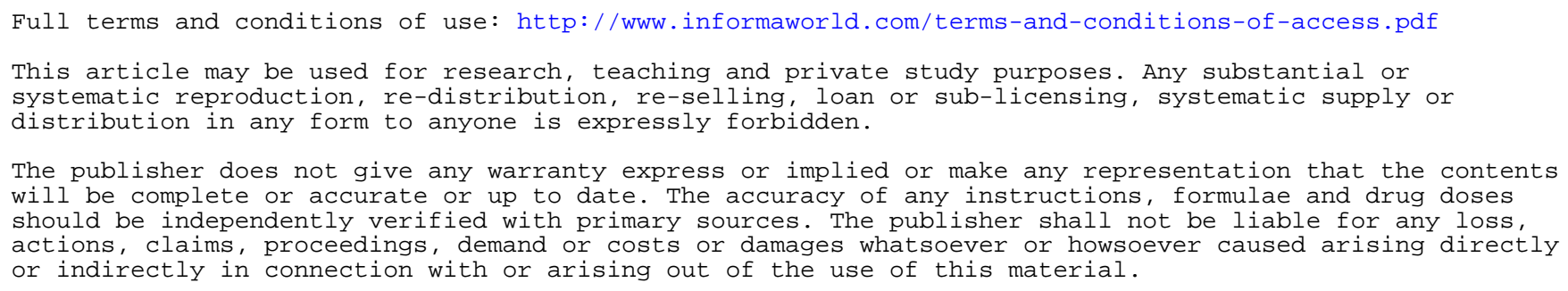




\title{
Highly localised distribution patterns of juvenile sea cucumber Australostichopus mollis
}

\author{
MJ Slater ${ }^{\mathrm{a} *}, \mathrm{AG}_{\text {Carton }}^{\mathrm{b}}$ and AG Jeffs ${ }^{\mathrm{c}}$ \\ ${ }^{a}$ School of Marine Science and Technology, Newcastle University, Newcastle upon Tyne, UK; ${ }^{b}$ School of \\ Marine and Tropical Biology, James Cook University, Townsville, Australia; ${ }^{c}$ Leigh Marine Laboratory, \\ University of Auckland, Warkworth, New Zealand
}

(Received 10 September 2009; final version received 23 June 2010)

Information on the environmental characteristics of the juvenile habitat of many deposit-feeding sea cucumber species is limited, despite most fished species exhibiting rapid localised depletion. The current study combined large and small scale surveying techniques within a New Zealand harbour to identify areas with high densities of juvenile Australostichopus mollis, a commercially valuable aspidochirote holothurian. Data from detailed surveys were used to relate densities of juveniles and adults with measures of physical habitat characteristics including depth, sediment facies type, grain size range, as well as measures of chlorophyll- $a$, phaeopigment, carbon and nitrogen content of surface sediment. Results revealed a highly localised distribution of juvenile A. mollis focused on one site associated with an area of high adult density. Sites of high juvenile A. mollis density were characterised by sediment qualities favouring epibenthic detritivorous deposit feeding, including high nitrogen content, high phaeopigment:chlorophyll- $a$ ratio and small grain size. The high-density juvenile site had facies that were further characterised by the presence of large shell fragments ( $>10 \mathrm{~cm}$ length) of the horse mussel (Atrina zelandica), which may provide a unique settlement microhabitat for early juveniles. Unlike some other sea cucumber species, juvenile A. mollis shows no distinct spatial separation from adult sea cucumbers, no association with dense macroalgae and no clear preference for shallower depths than adults. Overall, the results illustrate the highly localised pattern of recruitment of this species to a widely distributed adult population, which may help to explain the lack of previous observations of juveniles in this species. These results indicate the importance of identifying and protecting what appear to be very specific juvenile habitats in deposit-feeding sea cucumbers to ensure continuing recruitment to exploited populations.

Keywords: Australostichopus mollis; sea cucumber; juvenile habitat; localised distribution; sediment food value

\section{Introduction}

Many deposit-feeding sea cucumber species are heavily fished and exhibit rapid depletion in fished areas followed by slow population recovery (Skewes et al. 2000; Kinch 2002; Uthicke et al. 2004; Hearn et al. 2005; Conand 2006). Effective stock management is often limited, among other things, by a dearth of knowledge of juvenile habitat preferences and ecology. The majority of deposit-feeding sea cucumber species are seldom observed as juveniles in their natural habitat and descriptions of juvenile habitats are often limited to anecdotal information or chance observations revealing little more than depth, physical complexity of habitat and proximity to areas of high adult densities (Shiel 2004; James 2005). Nonetheless, chance events or intensive surveying have

*Corresponding author. Email:m.slater@ncl.ac.uk 
facilitated studies of a few deposit-feeding sea cucumber species in situ (Cameron \& Fankboner 1989; Wiedemeyer 1994; Mercier et al. 2000a; Yamana et al. 2006). In addition, nursery research and experiments involving the release of nursery-produced juveniles provide some information on juvenile sea cucumber survival in varying habitats (Battaglene 1999; Tanaka 2000; Dance et al. 2003; Purcell 2004; Dong \& Dong 2006).

Previous research has shown that both in the hatchery and in the natural environment, pentactula juvenile sea cucumbers show a preference for settling to planar surfaces or macroalgae with an associated biofilm, as opposed to soft sediment or complex substrates (Cameron \& Fankboner 1989; Wiedemeyer 1994; Ito \& Kitamura 1997; Battaglene et al. 1999; Mercier et al. 2000b; Toral-Granda et al. 2008). This solid substrate is abandoned, generally within 3 months, at which time juveniles migrate to adjacent complex or soft sediment substrate to begin feeding on particulates rather than biofilms or diatom films (Mercier et al. 2000b; Yaqing et al. 2000; Purcell 2004). The size at which juveniles move away from the settlement substrate varies widely between species and early forced migration negatively affects survival and growth (Wiedemeyer 1994; Battaglene et al. 1999; Mercier et al. 2000b; Purcell 2004; Purcell $\&$ Simutoga 2008). Migration from solid substrate appears to be primarily related to ontogenetic diet change, as it does not correspond with any recorded increase in ability to avoid predation by size or juvenile biochemical composition.

Juveniles remain highly cryptic in their behaviour after migration presumably as a predator avoidance mechanism (Hamel \& Mercier 1996; Mercier et al. 1999; Mercier et al. 2000b; Hamel et al. 2001; Dance et al. 2003). They are generally described in association with complex structure, frequently macroalgae, but also mangrove branches, the underside of rocks and coral fragments, as opposed to adults, which are commonly found in more exposed habitat (Choe 1963; Mosher
1980; Yingst 1982; Yamana et al. 2006). Yamana et al. (2006) describe high densities $\left(6.7 \mathrm{~m}^{-2}\right)$ of juvenile Apostichopus japonicus in the intertidal in association with large amounts of the macroalgae Sargassum spp. and Ulva spp., moderate eutrophication and protection from 'environmental fluctuation' (desiccation and high wave energy) during low tide. In addition to an association with complex structure, there is frequently, but not exclusively, a distinct spatial separation between juvenile and adult habitats with most deposit-feeding sea cucumber species exhibiting movement from shallow to deeper water as they increase in size from juvenile to adult (Cameron \& Fankboner 1989; Conand 1993; Mercier et al. 2000a; Hamel et al. 2001).

The juvenile distribution, habitat preferences and ecological requirements of the Australasian sea cucumber Australostichopus mollis are poorly understood and observations of juveniles are uncommon. Sewell (1987) reported that there is no depth correlation in the size distribution of $A$. mollis. Isolated juveniles have been encountered under boulders and in crevices in the same depth range and sites as adult specimens (personal observation) and three juveniles have previously been collected from under boulders adjacent to adult habitats (Sewell 1990; Mladenov \& Gerring 1991). Increasing fishing pressure and the obvious potential of A. mollis for aquaculture in New Zealand and Australia have recently stimulated increased research interest. In particular, research is focussed on larval biology and aquaculture methods with the aim of fulfilling the requirements for successful breeding and nursery rearing for developing commercial culture (Slater \& Carton 2007; Slater et al. 2009; Stenton-Dozey \& Heath 2009). Nonetheless, the almost complete lack of knowledge of juvenile habitat remains a significant shortfall in the understanding of this species. As with many other commercially important deposit-feeding sea cucumber species, the efficacy of $A$. mollis stock management, aquaculture and stock enhancement efforts will 
be greatly increased by improving knowledge of juvenile habitat requirements.

The current research investigates anecdotal reports and uses multiple scales of survey data from a harbour in northern New Zealand to refine the search for $A$. mollis juvenile habitat.

The research collects data regarding juvenile density and combines these with descriptions of sediment facies and sediment characteristics determined through physicochemical assays. These data are then combined and analysed to provide a novel description of juvenile $A$. mollis patterns of association and distribution.

On the basis of the previous research reviewed above, the authors define the most common elements of habitat association and juvenile distribution reported for juveniles of similar deposit-feeding sea cucumber species as spatial separation of juvenile and adult habitats including a depth gradient separation, and an association of juveniles with macroalgae or complex substrates. This research then determines whether juvenile $A$. mollis exhibit similar habitat associations and distribution pattern typical of other deposit-feeding species.

In addition to addressing this question, the research applies established measures of sediment physicochemistry to identify other potential associations of juveniles, in particular with sediment as a nutrient source for deposit-feeding sea cucumbers.

\section{Methods}

\section{Juvenile distribution surveying}

\section{Beam trawls}

The current study was conducted in the Mahurangi Harbour, a $25-\mathrm{km}^{2}$ shallow harbour on the east coast of the North Island of New Zealand ( $\left.36^{\circ} 27^{\prime} 0 \mathrm{~S}, 174^{\circ} 43^{\prime} 0 \mathrm{E}\right)$. The harbour was selected because of the reported high densities of $A$. mollis and availability of data from an extensive beam trawl survey covering all habitat types in the Mahurangi Harbour for juvenile fishes. Trawls sampling $600 \mathrm{~m}^{2}$ per trawl had been carried out using a beam trawl net (4-m wide beam with 3-m net opening, 6-m net length, 9-mm net mesh, 200-m tow length) towed by a shallow draught research vessel. Surveys were conducted on a quarterly basis between December 2005 and March 2007 with 36 or 48 trawls carried out per survey (total 252 trawls). Recorded data provided trawl position, trawl depth (1-18.5 m) and total number of adult sea cucumbers caught per trawl. Where sea cucumber numbers exceeded 50 per trawl (i.e. catch density of $>0.08 \mathrm{~m}^{-2}$ ), sites were plotted on a digital map to create an overview of high densities of sea cucumbers (Fig. 1). The contents of catches from the beam trawl survey of March 2007 (36 trawls) were analysed for presence of sub-adult or juvenile sea cucumbers. The location of sites where any sea cucumbers under $7 \mathrm{~cm}$ (juvenile) in length were captured was recorded and used to identify suitable locations for subsequent high-detail SCUBA transects sampling for juvenile densities and a range of habitat parameters. The maximum length for juveniles $(<7 \mathrm{~cm})$ corresponds to an average weight of less than $40 \mathrm{~g}$ and the size at first sexual maturity for this species which is in excess of $90 \mathrm{~g}$ (Raj 1998). A total of nine sites were selected by three criteria. Firstly, sites were selected on the basis of beam trawl results for the presence of juveniles (any site where juveniles were captured was included). Secondly, sites were selected where adult sea cucumber densities were in excess of $0.1 \mathrm{~m}^{-2}$. Thirdly, additional sites were included in areas where adult density was low and no juveniles were encountered in beam trawls. This third group of sites ensures the inclusion of sampling in all benthic habitat types within the harbour; sand, subtidal mud, sand, shell hash and horse mussel dominated facies (Morrison 2000).

\section{$S C U B A$ transects}

A series of three $50-\mathrm{m}^{2}$ SCUBA transects was then conducted at each of the nine sites within the Mahurangi Harbour in December 2007 and January 2008 (Sites A-I, Fig. 1). Transects 


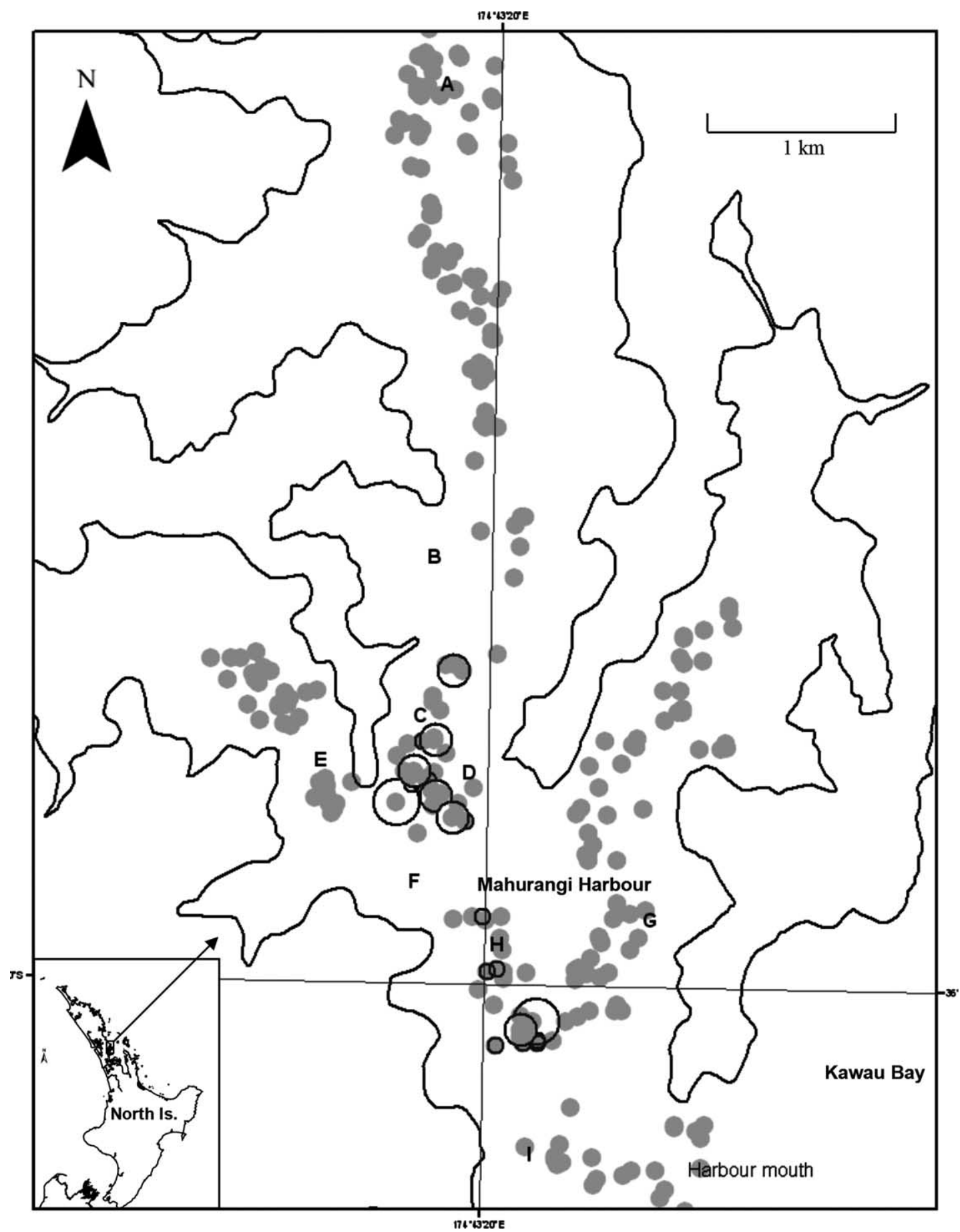

Fig. 1 The Mahurangi Harbour showing areas of high-density adult Australostichopus mollis as determined by $600-\mathrm{m}^{2}$ beam trawls; $=0.09-0.16 \mathrm{~m}^{-2} ;=0.17-0.33 \mathrm{~m}^{-2} ;=0.34-0.54 \mathrm{~m}^{-2}$. Letters indicate sites selected for $50-\mathrm{m}^{2}$ SCUBA transects. Grey circles indicate all beam trawls conducted between December 2005 and March 2007. 
were conducted by a SCUBA diver searching for animals $1 \mathrm{~m}$ either side of a $25-\mathrm{m}$ transect tape laid in a straight line along a randomly selected compass bearing. The start of each transect was selected at a random point within a 5-m radius of the anchor of the diver support vessel. The body length and position along the transect of any $A$. mollis found by a diver was measured and all animals $7 \mathrm{~cm}$ or less in length were recorded as juveniles. In addition, the depth, transect bearing and a sediment facies description was recorded for each transect. The presence or absence of adult sea cucumbers was recorded, as was the presence of any macroalgal growth. In May 2008, an additional set of three transects was conducted at the highest density juvenile site (D) to determine adult density and population structure at the site. The lengths of all $A$. mollis encountered $1 \mathrm{~m}$ either side of a $25-\mathrm{m}$ tape were recorded.

\section{Surface sediments}

Surface sediment samples (approximately $10 \mathrm{~g} \mathrm{WW}$ ) were taken at 5, 15 and $25 \mathrm{~m}$ along each transect adjacent to the tape. Samples were taken by inserting a $30-\mathrm{ml}$ plastic vial approximately $2-3 \mathrm{~mm}$ into the sediment surface and scraping the vial sideways to fill it with surface sediment. The sample vials have a $10-\mathrm{mm}$ opening and the vial insertion depth into the sediment surface was maintained at approximately midway between the base of the vial and the widest point of the vial opening. The variation of the sampling depth is expected to be a maximum of $1-2 \mathrm{~mm}$, and any samples where sediment exceeded the widest point of the vial opening were rejected by divers and resampled with new vials. Vials were sealed immediately and taken to the surface at the end of the transect dive. Samples were divided into three approximately equal sub-samples for physicochemical assays in the laboratory by twice drawing off approximately one third of each sample into clean marked vials from the original sample under constant vigorous mixing. All sub-samples were stored in a sealed chiller bin on the boat and returned to the laboratory within $2 \mathrm{~h}$. Samples were then wrapped in aluminium foil to protect them from light and stored at $-80^{\circ} \mathrm{C}$ until their use in physicochemical assays.

\section{Elemental carbon and nitrogen}

Surface sediment sub-samples (approximately $0.5 \mathrm{~g}$ ) were dried in a $60^{\circ} \mathrm{C}$ oven to constant weight $(48 \mathrm{~h})$. Dried samples were sieved over a $355-\mu \mathrm{m}$ sieve to remove shell fragments, ball ground and stored in 1.5-ml Eppendorf tubes before being analysed for total carbon and nitrogen using a Leco TruSpec elemental determinator.

\section{Phytopigment content}

Chlorophyll- $a$ and phaeopigment were determined using a variation of the spectrophotometric method initially described by Lorenzen (1967). Sub-samples ( $1 \mathrm{~g} \mathrm{WW}$ of sediment) were extracted with $100 \%$ acetone $(1.8 \mathrm{ml})$ and stored overnight at $4{ }^{\circ} \mathrm{C}$. Distilled water $(0.2 \mathrm{ml})$ was then added and the sample centrifuged at $4^{\circ} \mathrm{C}$ for $9 \mathrm{~min}$ at $3000 \mathrm{rpm}$. Extinction of $1 \mathrm{ml}$ of the supernatant was measured at 665 and $750 \mathrm{~nm}$ against a $90 \%$ acetone reference. $\mathrm{HCl}(40 \mu 110 \%)$ was then added to the supernatant for $4 \mathrm{~min}$. Extinction of the acidified supernatant was then measured at 665 and $750 \mathrm{~nm}$ against a $90 \%$ acetone reference (mean of three repeat measurements). Samples were then dried at $80^{\circ} \mathrm{C}$ for $48 \mathrm{~h}$ and weighed. Chlorophyll- $a$ and phaeopigment concentrations were calculated as follows:

$$
\begin{aligned}
& \text { Chlorophyll }-a \mu \mathrm{g} / \mathrm{g} \\
& \quad=[((A K(665 \mathrm{o}-665 \mathrm{a}) v / V l)]
\end{aligned}
$$

Phaeopigment $\mu \mathrm{g} / \mathrm{g}$

$$
=[(A K((R \times 665 \mathrm{a})-665 \mathrm{o}) v / V l)]
$$

where $A=11.0 \mu \mathrm{g}$, the inverse extinction coefficient for chlorophyll- $a$ in $90 \%$ acetone; $R=1.7$, maximum absorbance ratio for $665 \mathrm{o} / 665 \mathrm{a}$ 
without phaeopigment; $K=2.43 ; 6650$ and $665 \mathrm{a}$ are the absorbances before and after acidification respectively; $v=$ volume of acetone used in the extraction in $\mathrm{ml} ; \quad V=$ dry sediment weight in grams; $l=$ cuvette pathlength

\section{Grain size distribution}

Surface sediment sub-samples (approximately $1.5 \mathrm{~g} \mathrm{WW}$ of sediment) were treated for $4 \mathrm{~h}$ in a sodium metaphosphate solution $(5 \mathrm{~g} / \mathrm{l})$ to de-clump clay particles. Grain size distribution was then examined using a Malvern Mastersizer 2000 Particle Size Analyser using laser and blue light diffraction detection to determine sample grain size distribution (mean of three repeat measurements). Particles were grouped into six size ranges: 0-63, 64-125, 126-250, 251-500, 501-1000 and 1001-2000 $\mu \mathrm{m}$.

\section{Statistical analyses}

All sediment chemistry data were averaged by transect to simplify analyses, in particular for the correlation with the number of juveniles present on the transect. Data for each measure were $\log$ transformed where necessary to fulfil analysis of variance (ANOVA) assumptions and analysed for significant differences between sites using a one-way ANOVA. A Tukey HSD test post hoc analysis $(\alpha=0.05)$ was carried out on significant ANOVA results to identify pair-wise significant differences between site means. For each physicochemical characteristic of the sediment (including site depth), a rectangular matrix correlation analysis was used to test for significant correlation with the juvenile density. In addition, following the normalisation of variables, resemblance matrices were created for all sediment physicochemical characteristics (including site depth) measured for each transect on the basis of Euclidean distance. Multidimensional scaling (MDS) analysis was used to plot transect similarity by multiple factors. Eigenvector values were calculated using Spearman rank correlation coefficients to reveal the direction and scale of effect of individual variables on distribution of transects in multivariate space.

\section{Results}

\section{Juvenile distribution}

Analyses of all existing beam trawl data indicated the highest densities of adult sea cucumbers were centred on a region in the mid-harbour, although high numbers also extended to near the harbour mouth (Fig. 1). Analysis of March 2007 beam trawl catches, which were directly observed, showed that five juvenile sea cucumbers were captured in a single trawl. The location of the trawl site was accordingly included in sites selected for SCUBA transects (site D). SCUBA transect results confirmed the pilot beam trawl results including the presence of juvenile $A$. mollis at site D (Fig. 1). This area of relatively high density $\left(0.1-0.18 \mathrm{~m}^{-2}\right)$ of juvenile sea cucumbers is in mid-harbour in $11-12 \mathrm{~m}$ of water on a silt and mud dominated facies with occasional large horse mussel shell fragments (Atrina zelandica, shell $>10 \mathrm{~cm}$ length). The site also had a high density of adult $A$. mollis (0.72-1.14 $\mathrm{m}^{-2}$; Fig. 2). Juveniles were also encountered at much lower densities $\left(<0.05 \mathrm{~m}^{-2}\right)$ in three further transects at sites $\mathrm{F}$ and $\mathrm{H}$.

None of the sites surveyed by SCUBA exhibited macroalgal growth, although very occasional macroalgal debris was observed at sites D-I (mid-harbour to harbour mouth). Juveniles were situated on the sediment surface and frequently in small holes and gaps formed by large shell fragments. The size of juveniles ranged from 3 to $7 \mathrm{~cm}$ length. There was no obvious single year cohort structure to the population at site D. Sea cucumber length at the site ranged from 3 to $17 \mathrm{~cm}$ with a mean size of approximately $11 \mathrm{~cm}$ length. The size range from 3 to $7 \mathrm{~cm}$ is likely to represent 2 years of recruitment as the size of 1-year old laboratory reared $A$. mollis is reported to vary widely between 1.5 and $5 \mathrm{~cm}$ (Stenton-Dozey \& Heath 2009). 


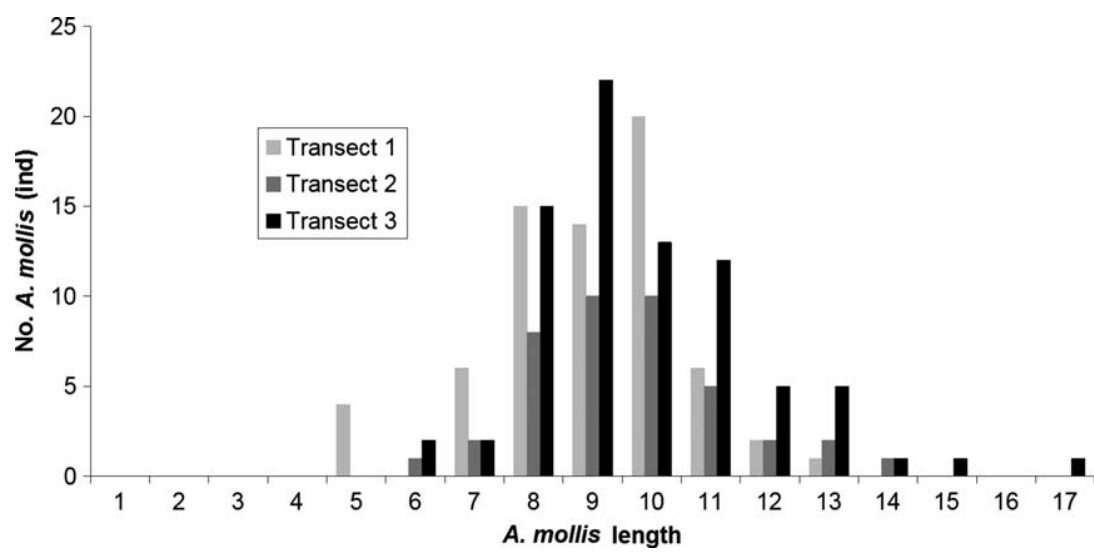

Fig. 2 Number of Australostichopus mollis encountered by length class in three $50-\mathrm{m}^{2}$ transects at site D in May 2008.

\section{Surface sediment characteristics}

One-way ANOVA analyses revealed significant differences amongst sites for all of the sediment chemistry measures. Post hoc analyses revealed complex groupings with the high-density juvenile site $\mathrm{D}$ located in homogenous groups (Tukey HSD $\alpha>0.05$ ) with downstream sites $\mathrm{G}, \mathrm{F}, \mathrm{H}$ or I for all measures apart from phaeopigment content (Fig. 3). Elemental carbon content of surface sediments ranged from $0.59 \% \mathrm{C}( \pm 0.03 \mathrm{SE})$ at site $\mathrm{E}$ to $1.82 \% \mathrm{C}$ $( \pm 0.08 \mathrm{SE})$ at site $\mathrm{I}$, and mean nitrogen content ranged from $0.11 \% \mathrm{~N}( \pm 0.002 \mathrm{SE})$ at site $\mathrm{E}$ through to $0.18 \% \mathrm{~N}( \pm 0.002 \mathrm{SE})$ at site $\mathrm{D}$.

Phytopigment values from the sampled sediments were highly variable between sites (Fig. 3). Chlorophyll- $a$ was lowest at site D (3.7 $\mu$ g chl $a$ per g sediment $\pm 0.6 \mathrm{SE})$ while site $\mathrm{E}$ had both the highest sediment chlorophyll- $a$ content $(10.2 \mu \mathrm{g}$ chl $a$ per g sediment $\pm 0.5 \mathrm{SE})$ and the lowest phaeopigment concentration (2.53 $\mu \mathrm{g}$ phaeopigment per $\mathrm{g}$ sediment \pm 0.2 $\mathrm{SE})$. Site $\mathrm{H}$ exhibited the highest mean phaeopigment concentration $(6.37 \mu \mathrm{g}$ phaeopigment per g sediment $\pm 0.43 \mathrm{SE}$ ). The phaeopigment to chlorophyll- $a$ ratio was also highly variable. Site D exhibited the highest value and was significantly different from all sites except site B (Tukey HSD $\alpha<0.05$ ).

Sites $\mathrm{H}$ and $\mathrm{D}$ were shown to be silt and clay dominated $(0-63 \mu \mathrm{m})$ with a further large proportion of very fine sand $(64-125 \mu \mathrm{m})$ (Fig. 4). Sites F, G, B and C exhibited a more equal proportioning between silt and very fine sand with increased fine sand content at site C. Sites I, A and E had a high proportion of silt, but with a higher content of medium sand and coarse sand.

\section{Correlation of site characteristics with juvenile density}

Total nitrogen, phaeopigment/chlorophyll- $a$ ratio, depth and GSA silt fraction all exhibited significant positive correlations with increasing number of juveniles (Table 1). Chlorophyll- $a$ content was the only factor that exhibited a significant negative correlation with increasing juvenile numbers (Table 1). An MDS plot of all sediment characteristics showed strong grouping (Euclidean distance $=3.8$ ) among transects at sites $\mathrm{D}$ and $\mathrm{H}$ where juveniles were encountered (Fig. 5). The eigenvector plot shows a strong positive MDS $y$ contribution for silt content and nitrogen content as opposed to fine sand content, which is strongly negative (Fig. 6). The MDS $x$ positive consists approximately equally of phaeopigment content, phaeopigment:chlorophyll- $a$ ratio, depth and carbon content, with a strong negative contribution by chlorophyll- $a$ content. 

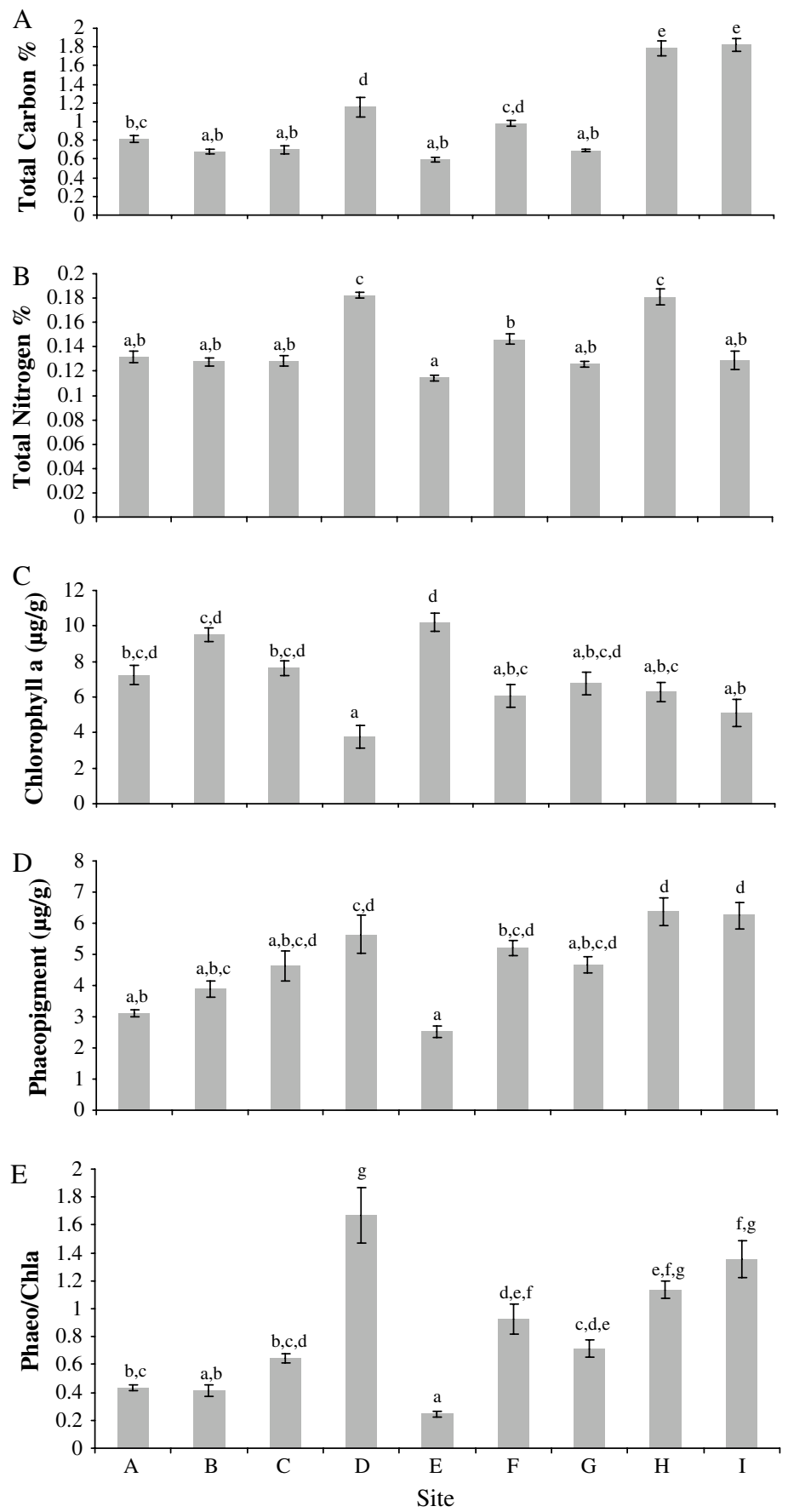

Fig. 3 Physiochemical characteristics of surface sediments for each survey site: A, total carbon; B, total nitrogen; $\mathrm{C}$, chlorophyll- $a$; D, phaeopigment; E, phaeopigment/chlorophyll- $a$ ratio; error bars indicate standard error of the mean. Lower case letters indicate groups after pair-wise comparison. 


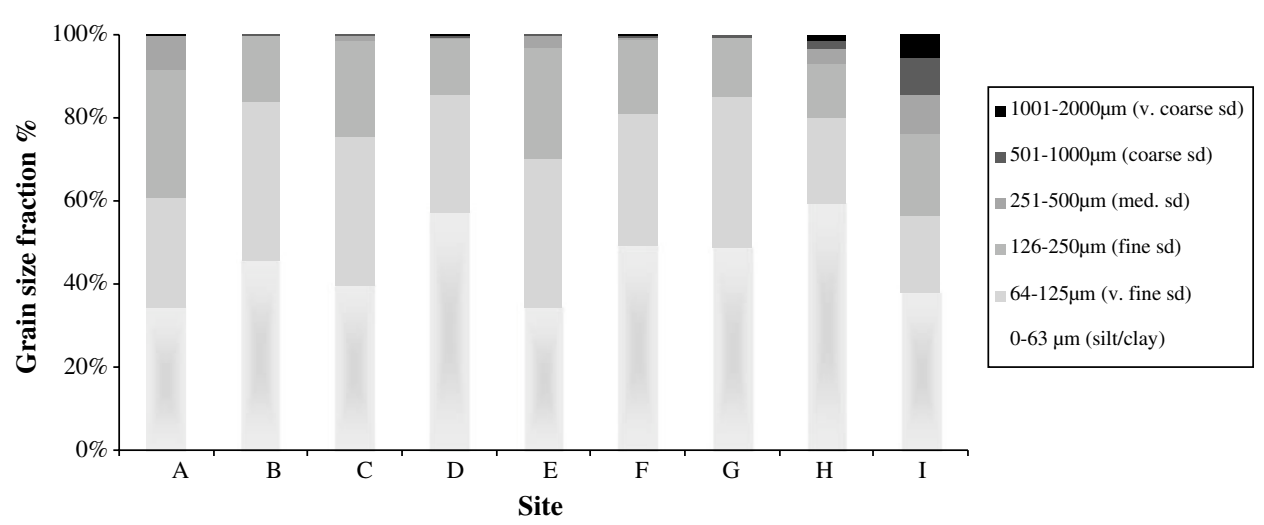

Fig. 4 Grain size distribution of surface sediments for each survey site.

\section{Discussion}

The recruitment processes of many commercially important deposit-feeding sea cucumber species remain poorly understood because of a lack of knowledge of juvenile habitat preferences (Shiel 2004; James 2005). The current research describes the highly localised distribution of juveniles of the sea cucumber A. mollis associated with specific habitat and sediment characteristics. Nine sites, which included all

Table 1 Relationship between juvenile sea cucumber abundance and a range of physiochemical sediment characteristics for nine sampled sites in the Mahurangi Harbour.

\begin{tabular}{lcc}
\hline $\begin{array}{l}\text { Sediment } \\
\text { characteristic }\end{array}$ & $\begin{array}{c}\text { Correlation } \\
(r)\end{array}$ & $\begin{array}{c}\text { Level of sig. } \\
(P)\end{array}$ \\
\hline$\%$ Nitrogen & 0.6570 & $>0.000$ \\
$\%$ Carbon & 0.1493 & 0.457 \\
Chl $a, \mu \mathrm{g} / \mathrm{g}$ sed & -0.5594 & 0.002 \\
Phaeo, $\mu \mathrm{g} / \mathrm{g}$ sed & 0.2132 & 0.286 \\
Phaeo $/ \mathrm{chl} a$, sed & 0.5896 & 0.001 \\
$0-63 \mu \mathrm{m} \mathrm{GF}$ & 0.4969 & 0.008 \\
$64-125 \mu \mathrm{m}$ GF & -0.1415 & 0.481 \\
$126-250 \mu \mathrm{m}$ GF & -0.3597 & 0.065 \\
$251-500 \mu \mathrm{m}$ GF & -0.2601 & 0.190 \\
$501-1000 \mu \mathrm{m}$ GF & -0.1217 & 0.545 \\
$1001-2000 \mu \mathrm{m}$ GF & -0.1205 & 0.549 \\
Depth, m & 0.5015 & 0.008 \\
\hline
\end{tabular}

chl $a$, chlorophyll- $a$; phaeo, phaeopigment; GF, grain size fraction. predominant benthic habitat types within the Mahurangi Harbour, were surveyed. The three sites where juvenile sea cucumbers were encountered did not exhibit the expected elements associated with habitats of juveniles of other sea cucumber species. However,the juvenile sites shared similar grain size distributions, high phaeopigment concentrations and high nitrogen content compared with all other sites surveyed.

Sediment characteristics appeared best to explain the distribution of juveniles that was observed. MDS plots were used to show that sediment characteristics closely grouped all of the sites where juvenile A. mollis were encountered - sites D, H and F (Fig. 5). Site D is of particular interest because of the presence of much higher densities of juveniles than any other site surveyed $\left(0.1-0.2 \mathrm{~m}^{-2}\right)$. It differs most strongly from all other sites in its high nitrogen content, low chlorophyll- $a$ and high phaeopigment:chlorophyll- $a$ ratio. MDS plots tightly grouped transects in which juveniles were present with the exception of one transect at site F (Fig. 5). Silt and clay content, nitrogen content, increasing depth, phaeopigment content and phaeopigment:chlorophyll- $a$ ratio showed positive eigenvector contributions towards increasing juvenile densities (Fig. 6). This supports the correlation results for the individual physiochemical variables in relation 


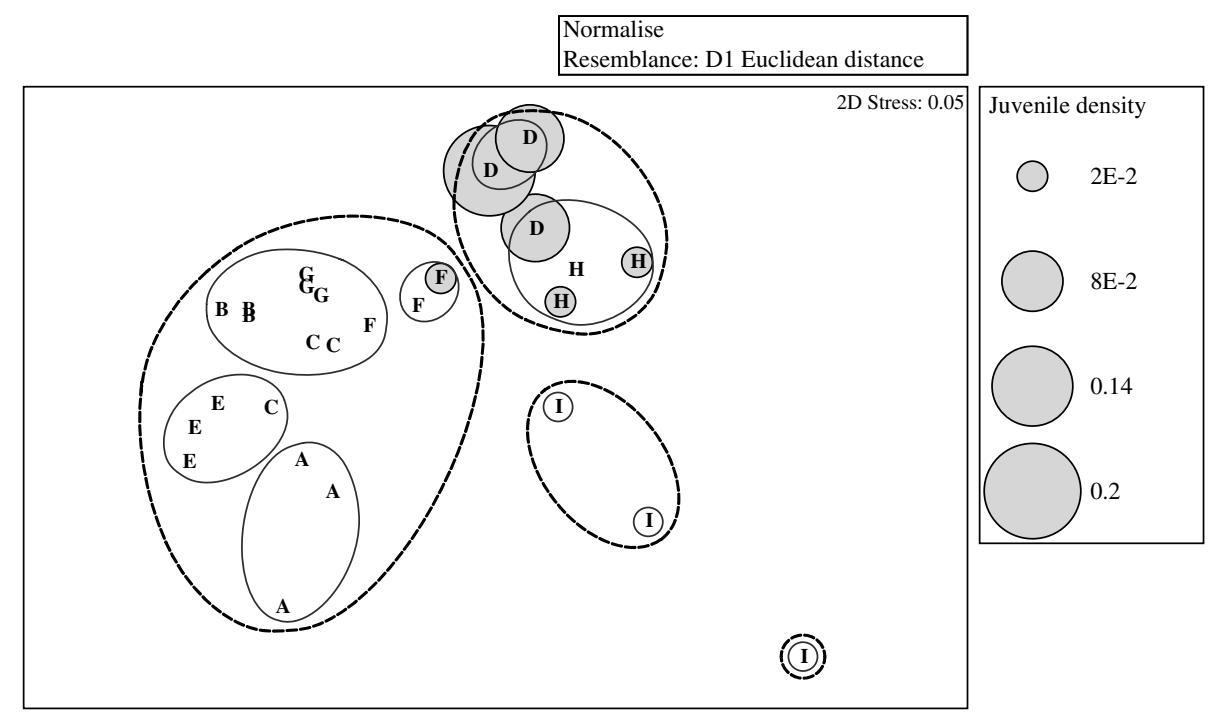

Fig. 5 Multidimensional scaling plot of 27 transects conducted at nine survey sites within the Mahurangi Harbour. Transects are grouped by Euclidian distance similarity based on cluster analysis of all physicochemical sediment characteristics from surface sediments collected for each transect and depth. Individual transects are marked with site identification letters (A-I). Juvenile density at each transect is indicated by bubble plot.

to juvenile density, with the exception of phaeopigment.

Overall, these results can be interpreted as representing superior food availability for detritivores at the sites where juveniles are present, in particular site $\mathrm{D}$. The smaller grain size profile of the sediment at site D is likely to offer high food quality not only through associated bacterial activity, but also through the surfacerich nature of smaller grains with an associated organic monolayer offering a rich food source (Mayer et al. 1985; Yamamoto \& Lopez 1985). The high content of nitrogen, carbon and phaeopigment in sediment at site D in comparison to most other sites surveyed indicates considerable allochthonous inputs including algal detrital and terrigenous detrital input. The low chlorophyll- $a$ content of sediment at site D shows comparatively low benthic primary productivity, which is logical given the depth (11-12 m), high turbidity and low sediment incident light levels encountered at this site (Gibbs et al. 2005). High chlorophyll- $a$ content has been shown to induce selective feeding by $H$. scabra and chlorophyll- $a$ is readily assimilated from food sediments by certain tropical sea cucumber species (Uthicke 1999; Uthicke \& Karez 1999). However, it is probable that $A$. mollis, which inhabits waters to depths exceeding $200 \mathrm{~m}$ exhibits more distinctly detritivorous feeding preferences than shallow-water tropical species, or perhaps are simply opportunistic in their assimilation of available organic matter (Pawson 1970; Hammond 1983; Gao et al. 2008).

The high phaeopigment:chlorophyll- $a$ ratio at site $\mathrm{D}$ is indicative of a more advanced degradative state of particulate organic matter reaching the sediment, but may also indicate high rates of grazing at the sediment surface (Welschmeyer \& Lorenzen 1985). High nitrogen content at sites $\mathrm{D}$ and $\mathrm{H}$ in comparison to other sediments within the harbour also indicate higher bacterial activity (Lopez 1987). Increased decomposition and bacterial content of both terrigenous and macroalgal detritus greatly improves the digestibility of organic matter to holothurians and bacterial content is 


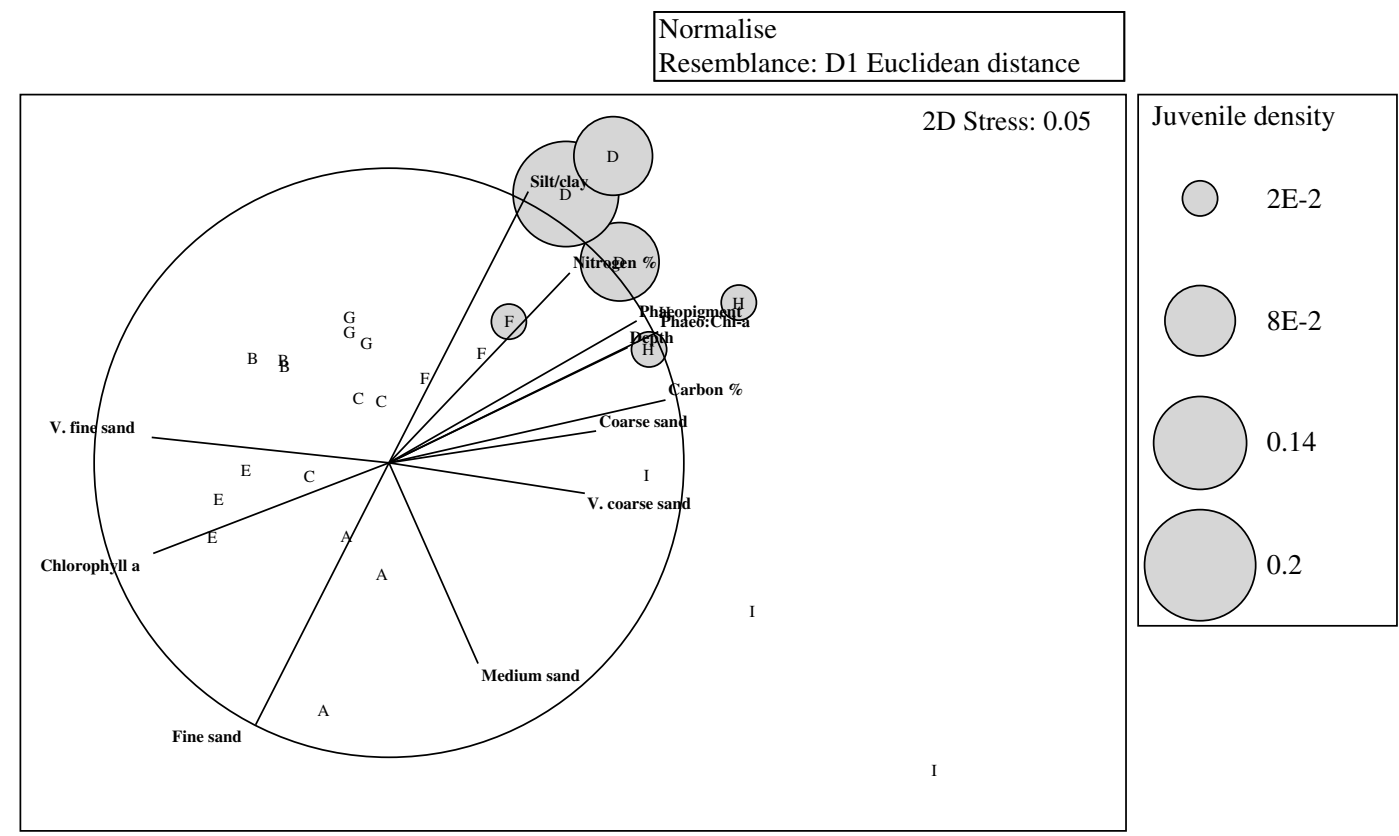

Fig. 6 Multidimensional scaling plot of 27 transects at nine survey sites within the Mahurangi Harbour. Individual transects are plotted by all physicochemical sediment characteristics from surface sediments collected for each transect and depth. Eigenvectors displayed are Spearman rank correlation coefficients for all variables. Individual transects are marked with site identification letters (A-I). Juvenile density at each transect is indicated by bubble plot.

selectively consumed by several tropical aspidochirote species (Yingst 1976; Moriarty 1982). Moriarty et al. (1985) also showed the importance of bacteria in transformation of organic matter in the benthos and their important role as a food source for sea cucumbers. Wing et al. (2008) recently used stable isotope analysis to show that $A$. mollis derives organic matter from refractory algal and terrestrial carbon sources only after bacterial recycling. However, bacterial carbon itself is considered a relatively lowdensity carbon source in sediments and is unlikely to be the primary carbon source in the sediment diets of detritivores (Nealson 1997). In sediments with high bacterial activity and low primary productivity, the amorphous aggregated sedimentary organic matter resulting from bacterial digestion and exoenzyme activity presents a significant additional nutrient source available to detritivores (Lopez 1987; Nealson 1997).
The subtidal macrofauna in Mahurangi Harbour is dominated by detritivorous species Theora lubrica along with oligochaetes and the polychaete Pironospio sp. (Ellis et al. 2006). However, species diversity is significantly lower in the subtidal Mahurangi Harbour than in the intertidal and in comparable harbours in northeastern New Zealand (Ellis et al. 2006). The density of detritivorous macrofauna is only $25 \%$ that of intertidal sites in the Mahurangi Harbour and in comparable harbours despite high organic content and suspended sediments (Gibbs et al. 2005; Ellis et al. 2006). Juvenile sea cucumbers at site D face markedly lower competition with other detritivores for surface sediment organic content. Alternatively, large numbers of juvenile and adult sea cucumbers feeding on the available sediment detritus may simply be excluding other detritivores from the site. 
Physicochemical analyses of associated surface sediments reveal a strong association of juvenile density with specific sediment and facies characteristics. Distribution and density of juveniles correlates well with increasing organic matter availability in diet sediments as reported previously for adult sea cucumbers in sandy or muddy environments (Massin 1982; Sibuet 1984). The observed association of juvenile A. mollis with specific sediment characteristics does not, however, exclude the role of other potential factors in determining juvenile distribution. These other factors include hydrodynamics influencing larval distribution (which have been shown to concentrate larvae of other benthic species in mid-harbour within the Mahurangi Harbour), settlement surface preferences, or the influence of early juvenile mortality as a result of predation or other unknown environmental factors (Harrison 1974; Martin \& Foster 1986; Osman et al. 1992; Gosselin \& Qian 1997).

Predator avoidance behaviour did not appear to influence the observed densities of juvenile $A$. mollis. In many hours of SCUBA diving over 3 years of research at this site, the juvenile $A$. mollis at this site were never seen exhibiting the defensive burrowing behaviour frequently observed in the juveniles of other deposit-feeding sea cucumber species (Pawson 1970; Mercier et al. 1999).

Previous studies have reported a distinct spatial separation between juvenile and adult populations of deposit-feeding sea cucumbers (Cameron \& Fankboner 1989; Mercier et al. 2000a). In comparison, we found large numbers of adult sea cucumbers in the area where juveniles were present (Fig. 2). Despite there being no distinct separation between the two size groups, there is a size-related element to distribution of $A$. mollis within the harbour, with adults present in considerable numbers in several areas where juveniles are not present. The separation of juveniles and adults of deposit-feeding sea cucumber species has frequently been described as following a depth gradient with juveniles in shallow waters or even the intertidal (Bulteel et al. 1992; Conand 1993; Hamel \& Mercier 1996; Conand 2006; Yamana et al. 2006). The current research on A. mollis shows an opposite trend, with increasing juvenile density positively correlated with greater depth, and with large numbers of A. mollis located within one of the deepest areas of mid-harbour and absent in considerably shallower adjacent areas.

Holothuria scabra associates with seagrass at settlement and early post-settlement, while $P$. californicus is associated with filamentous algal mats and A. japonicus is found considerably later in juvenile development associated with the seagrass Zostera japonica, and the macroalgae Ulva spp. and Sargassum spp. (Choe 1963; Cameron \& Fankboner 1989; Mercier et al. 2000b; Yamana et al. 2006). The association of juvenile $A$. japonicus with seagrass and macroalgae was thought to be related to the availability of algal detritus as a food source (Yamana et al. 2006), whereas cryptic behaviour of juvenile $P$. californicus in algal mats was interpreted as predator avoidance (Cameron \& Fankboner 1989). Holothuria scabra settles directly to seagrass blades before migrating to sediment at about $10 \mathrm{~mm}$ in length (Mercier et al. 2000b). The area of high juvenile $A$. mollis abundance found in this study has no macroalgae and there is minimal macroalgae present in the adjacent intertidal areas. The lack of macroalgae negates the likelihood of $A$. mollis settling to macroalgae at site D. Clumps of macroalgal detritus were periodically observed being swept through the area by tidal water movement during transect dives, but it is unclear whether these make a significant contribution as a detrital food supply and/or settlement habitat.

If juveniles are settling directly at site $\mathrm{D}$, the most likely settlement surface appears to be shell fragments of the large horse mussel (Atrina zelandica), which is prevalent at the site, as they represent the only solid planar surface available. These shell fragments are found at several other sites surveyed, and large shell fragments of the scallop Pecten novaezelandiae are present at outer harbour sites. Juveniles were often found 
in contact with larger shell fragments, either fully enclosed within fragments, or at least with part of the body attached to, or touching shell fragments. This preference for contact with at least one solid planar surface, even when extending the anterior end over soft sediment to feed, has been described previously in adult A. mollis (Slater 2006). It is possible that this behaviour, in particular full concealment of juveniles within large shell fragments, could be a form of predator avoidance, although predators of this species remain unknown (Sewell 1987). It is possible that larger shell fragments provide a hard settlement surface for larvae and a refuge for small juveniles ( $<10 \mathrm{~mm}$ length) prior to migration to soft sediments (Wiedemeyer 1994). However, primary benthic productivity is low at site D meaning there would be few benthic diatoms available as a food source to post-settlement juveniles prior to early juveniles beginning to feed on soft sediments. In this case, juveniles may be settling and feeding directly on decaying detritus or bacterial biofilms associated with the shell fragments as opposed to the preference of other species for high chlorophyll- $a$ content in sediments (Uthicke \& Karez 1999). If $A$. mollis alternatively conforms to the general settlement pattern frequently described for sea cucumbers, with settlement to planar surfaces in shallow water followed by juvenile migration to deeper sites and associated deposit feeding, then site D is more likely to represent an early migration site (Conand 1993; Hamel \& Mercier 1996; Mercier et al. 2000b). In this case, any migration to the site will nonetheless take place from areas with negligible macroalgal growth but offering considerable bivalve shell hash and planar surfaces in the form of subtidal rock wall as potential settlement surfaces and immediate post-settlement habitat.

\section{Conclusion}

The research found a highly localised pattern of recruitment of a commercially important deposit-feeding sea cucumber within a large harbour in north-eastern New Zealand. Patterns of distribution of juvenile sea cucumbers are explained well by physicochemical properties of the surface sediments at the sites surveyed, in particular several properties commonly linked to increased degradative state and increasing food availability for deposit-feeding detritivores. The distribution of the juvenile $A$. mollis differs from that commonly described for other deposit-feeding sea cucumbers in its lack of association with macroalgae, the absence of a distinct separation between adults and juveniles, as well as an unusual association of juveniles with deeper water. The highly localised pattern of recruitment may help to explain the previous lack of observations of juveniles of this species in the wild. The observed highly localised distribution also emphasises the importance of identifying and protecting juvenile habitats in order to preserve fished sea cucumber populations effectively.

\section{Acknowledgements}

Many thanks to Dr Mary Sewell for her advice and insights and to Dr Natalie Usmar for the provision of pilot study information and the 2007 beam trawl juvenile sampling. Thanks to Richard Griffiths, Charles Bedford, Adam Cowles and Dr Craig Radford for field work assistance. This research was funded through a University of Auckland doctoral fellowship. Thanks also to the reviewers of this manuscript for constructive and useful suggestions.

\section{References}

Battaglene SC 1999. Culture of tropical sea cucumbers for stock restoration and enhancement. NAGA 22: 4-11.

Battaglene SC, Seymour JE, Ramofafia C 1999. Survival and growth of cultured juvenile sea cucumbers, Holothuria scabra. Aquaculture 178: 293-322.

Bulteel P, Jangoux M, Coulon P 1992. Biometry, bathymetric distribution, and reproductive cycle of the holothuroid Holothuria tubulosa (Echinodermata) from Mediterranean seagrass beds. Marine Ecology 13: 53-62. 
Cameron JL, Fankboner PV 1989. Reproductive biology of the commercial sea cucumber Parastichopus californicus (Stimpson) (Echinodermata: Holothuroidea). II. Observations on the ecology of development, recruitment, and the juvenile life stage. Journal of Experimental Marine Biology and Ecology 127: 43-67.

Choe S 1963. Biology of the Japanese common sea cucumber Stichopus japonicus Selenka. Pusan, Pusan National University.

Conand C 1993. Ecology and reproductive biology of Stichopus variegatus an Indo-Pacific coral reef sea cucumber (Echinodermata: Holothuroidea). Bulletin of Marine Science 52: 970-981.

Conand C 2006. Sea cucumber biology: taxonomy; distribution; biology; conservation status. In: Bruckner AW ed. The Proceedings of the CITES workshop on the conservation of sea cucumbers in the families Holothuriidae and Stichopodidae. NOAA. p. 244.

Dance SK, Lane L, Bell JD 2003. Variation in shortterm survival of cultured sandfish (Holothuria scabra) released in mangrove-seagrass and coral reef flat habitats in Solomon Islands. Aquaculture 220: 495-505.

Dong YW, Dong SL 2006. Growth and oxygen consumption of the juvenile sea cucumber Apostichopus japonicus (Selenka) at constant and fluctuating water temperatures. Aquaculture Research 37: 1327-1333.

Ellis J, Ysebaert T, Hume T, Norkko A, Bult T, Herman P, Thrush S, Oldman J 2006. Predicting macrofaunal species distributions in estuarine gradients using logistic regression and classification systems. Marine Ecology Progress Series 316: 69-83.

Gao F, Yang H, Xu Q, Wang F, Liu G, German DP 2008. Phenotypic plasticity of gut structure and function during periods of inactivity in Apostichopus japonicus. Comparative Biochemistry and Physiology Part B: Biochemistry and Molecular Biology 150: 255-262.

Gibbs M, Funnell G, Pickmere S, Norkko A, Hewitt J 2005. Benthic nutrient fluxes along an estuarine gradient: influence of the pinnid bivalve Atrina zelandica in summer. Marine Ecology Progress Series 288: 151-164.

Gosselin LA, Qian PY 1997. Juvenile mortality in benthic invertebrates. Marine Ecology Progress Series 146: 265-282.

Hamel JF, Mercier A 1996. Early development, settlement, growth, and spatial distribution of the sea cucumber Cucumaria frondosa (Echinodermata: Holothuroidea). Canadian Journal of Fisheries and Aquatic Sciences 53: 253-271.
Hamel JF, Conand C, Pawson DL, Mercier A 2001. The sea cucumber Holothuria scabra (Holothuroidea: Echinodermata): its biology and exploitation as beche-de-mer. Advances in Marine Biology 41: 129-223.

Hammond LS 1983. Nutrition of deposit-feeding holothuroids and echinoids (Echinodermata) from a shallow reef lagoon, Discovery Bay, Jamaica. Marine Ecology Progress Series 10: 297-305.

Harrison G 1974. Mahurangi Harbour Marine Studies. Report for the Auckland Regional Authority. Harrison Grierson and Partners. p. 65 .

Hearn A, Martinez P, Toral-Granda MV, Murillo JC, Polovina J 2005. Population dynamics of the exploited sea cucumber Isostichopus fuscus in the western Galapagos Islands, Ecuador. Fisheries Oceanography 14: 377-385.

Ito S, Kitamura H 1997. Induction of larval metamorphosis in the sea cucumber Stichopus japonicus by periphitic diatoms. Hydrobiologia 358: 281-284.

James DB 2005. Information on juvenile holothurians. SPC beche-de-mer Information Bulletin 21: $26-27$.

Kinch J 2002. The beche-de-mer fishery in the Milne Bay Province of Papua New Guinea. A report to the National Fisheries Authority, Port Moresby, Papua New Guinea \& CSIRO, Queensland, Australia.

Lopez GR 1987. Ecology of deposit-feeding animals in marine sediments. Quarterly Review of Biology 62: 235-260.

Lorenzen CJ 1967. Determination of chlorophyll and pheo-pigments: spectrophotometric equations. Limnology and Oceanography 12: $343-$ 346.

Martin AT, Foster BA 1986. Distribution of barnacle larvae in Mahurangi Harbour, North Auckland. New Zealand Journal of Marine and Freshwater Research 20: 67-76.

Massin C 1982. Food and feeding mechanisms: Holothuroidea. In: Jangoux M, Lawrence JM eds. Echinoderm nutrition. Rotterdam, AA Balkema. Pp. 43-55.

Mayer LM, Rahaim PT, Guerin W, Macko SA, Watling L, Anderson FE 1985. Biological and granulometric controls on sedimentary organic matter of an intertidal mudflat. Coastal and Shelf Science 20: 491-503.

Mercier A, Battaglene SC, Hamel JF 1999. Daily burrowing cycle and feeding activity of juvenile sea cucumbers Holothuria scabra in response to environmental factors. Journal of Experimental Marine Biology and Ecology 239: 125-156. 
Mercier A, Battaglene SC, Hamel JF 2000a. Periodic movement, recruitment and size-related distribution of the sea cucumber Holothuria scabra in Solomon Islands. Hydrobiologia 440: 81-100.

Mercier A, Battaglene SC, Hamel JF 2000b. Settlement preferences and early migration of the tropical sea cucumber Holothuria scabra. Journal of Experimental Marine Biology and Ecology 249: 89-110.

Mladenov PV, Gerring P 1991. Resource evaluation of the sea cucumber (Stichopus mollis) in Fiordland, New Zealand. Dunedin, Marine Science and Aquaculture Research Centre, University of Otago.

Moriarty DJW 1982. Feeding of Holoturia atra and Stichopus chloronotus on bacteria, organic carbon and organic nitrogen in sediments of the Great Barrier Reef. Australian Journal of Marine and Freshwater Research 33: 255-263.

Moriarty DJW, Pollard PC, Hunt W.G, Moriarty CM, Wassenberg TJ 1985. Productivity of bacteria and microalgae and the effect of grazing by holothurians in sediments on a coral flat. Marine Biology 85: 293-300.

Morrison MA 2000. Mahurangi Harbour Habitat Map, NIWA Information Series no. 13. Wellington, National Institute of Water and Atmospheric Research. Pp. 1. Map, colour.

Mosher C 1980. Distribution of Holothuria arenicola Semper in the Bahamas with observations on habitat, behaviour and feeding activity (Echinodermata, Holothuroidea). Bulletin of Marine Science 30: 1-12.

Nealson KH 1997. Sediment bacteria: who's there, what are they doing, and what's new? Annual Review of Earth and Planetary Sciences 25: 403-434.

Osman RW, Whitlatch RB, Malatesta RJ 1992. Potential role of micropredators in determining recruitment into a marine community. Marine Ecology Progress Series 83: 35-43.

Pawson DL 1970. The marine fauna of New Zealand: sea cucumbers (Echinodermata: Holthuroidea). Bulletin (New Zealand Department of Scientific and Industrial Research). Pp. 69.

Purcell SW 2004. Criteria for release strategies and evaluating the restocking of sea cucumbers. In: Lovatelli A, Conand C, Purcell SW, Uthicke S, Hamel J.-F, Mercier A eds. Advances in sea cucumber aquaculture and management. Dalian, FAO. p. 439.

Purcell SW, Simutoga M 2008. Spatio-temporal and size-dependent variation in the success of releasing cultured sea cucumbers in the wild. Reviews in Fisheries Science 16: 204-214.
Raj LK 1998. Reproductive biology and the use of photoidentification to study growth in Stichopus mollis (Echinodermata: Holothuroidea) in Doubtful Sound, Fiordland, New Zealand. Dunedin, University of Otago.

Sewell MA 1987. The reproductive biology of Stichopus mollis (Hutton), Department of Zoology. Auckland, University of Auckland. p. 98.

Sewell MA 1990. Aspects of the ecology of Stichopus mollis (Echinodermata: Holothuroidea) in north-eastern New Zealand. New Zealand Journal of Marine and Freshwater Research 24: 97-103.

Shiel G 2004. Field observations of juvenile sea cucumbers. SPC beche-de-mer Information Bulletin 20: 6-11.

Sibuet M 1984. Quantitative distribution of echinoderms (Holothuroidea, Asteroidea, Ophiuroidea, Echinoidea) in relation to organic matter in the sediment in deep sea basins of the Atlantic Ocean. In: Keegan BF, O'Connor BDS eds. International Echinoderm Conference. Galway, CRC. Pp. 99-108.

Skewes TD, Dennis DM, Burridge CM 2000. Survey of Holothuria scabra (sandfish) on Warrior Reef, Torres Strait, January, 2000: CSIRO Division of Marine Research Final Report. Cleveland, Qld, CSIRO Division of Marine Research.

Slater MJ 2006. Polyculture of the sea cucumber Stichopus mollis with green-lipped mussels, Leigh Marine Laboratory. Auckland, University of Auckland. p. 112.

Slater MJ, Carton AG 2007. Survivorship and growth of the sea cucumber Australostichopus (Stichopus) mollis (Hutton 1872) in polyculture trials with green-lipped mussel farms. Aquaculture 272: 389-398.

Slater MJ, Jeffs AG, Carton AG 2009. The use of the waste from green-lipped mussels as a food source for juvenile sea cucumber, Australostichopus mollis. Aquaculture 292: 219-224.

Stenton-Dozey J, Heath P 2009. A first for New Zealand: culturing our endemic sea cucumber for overseas markets. Water \& Atmosphere 17: $20-21$.

Tanaka M 2000. Diminution of sea cucumber Stichopus japonicus juveniles released on artificial reefs. Bulletin of Ishikawa Prefecture Fisheries Resource Center 2: 19-29.

Toral-Granda V, Lovatelli A, Vasconcellos M 2008. Sea cucumbers - A global review of fisheries and trade. Rome, FAO.

Uthicke S 1999. Sediment bioturbation and impact of feeding activity of Holothuria (Halodeima) 
atra and Stichopus chloronotus, two sediment feeding holothurians, at Lizard Island, Great Barrier Reef. Bulletin of Marine Science 64: 129-141.

Uthicke S, Karez R 1999. Sediment patch selectivity in tropical sea cucumbers (Holothurioidea: Aspidochirotida) analysed with multiple choice experiments. Journal of Experimental Marine Biology and Ecology 236: 69-87.

Uthicke S, Welch D, Benzie JAH 2004. Slow growth and lack of recovery in overfished holothurians on the Great Barrier Reef: Evidence from DNA fingerprints and repeated large-scale surveys. Conservation Biology 18: 1395-1404.

Welschmeyer NA, Lorenzen CJ 1985. Chlorophyll budgets: zooplankton grazing and phytoplankton growth in a temperate fjord and the Central Pacific Gyres. Limnology and Oceanography 30: $1-21$.

Wiedemeyer WL 1994. Biology of small juveniles of the tropical holothurian Actinopyga echinites: growth, mortality, and habitat preferences. Marine Biology 120: 81-93.

Wing SR, McLeod RJ, Clark KL, Frew RD 2008. Plasticity in the diet of two echinoderm species across an ecotone: microbial recycling of forest litter and bottom-up forcing of population structure. Marine Ecology Progress Series 360: 115-123.

Yamamoto N, Lopez G 1985. Bacterial abundance in relation to surface area and organic content of marine sediments. Journal of Experimental Marine Biology and Ecology 90: 209-220.

Yamana Y, Hamano T, Miki K 2006. Distribution of the Japanese sea cucumber Apostichopus japonicus in the intertidal zone of Hirao Bay, eastern Yamaguchi Prefecture, Japan-Suitable environmental factors for juvenile habitats. Journal of National Fisheries University 54: 111-120.

Yaqing C, Changqing Y, Xin S 2000. Sea cucumber (Apostichopus japonicus) pond polyculture in Dalian, Liaoning Province, China. Advances in Sea Cucumber Aquaculture and Management (ASCAM ) Conference, Dalian, Liaoning Province, China.

Yingst JY 1976. The utilization of organic matter in shallow marine sediments by an epibenthic deposit-feeding holothurian. Journal of Experimental Marine Biology and Ecology 23: 55-69.

Yingst JY 1982. Factors influencing rates of sediment ingestion by Parastichopus parvimensis (Clark), an epibenthic deposit-feeding holothurian. Estuarine Coastal and Shelf Science 14: 119-134. 